\title{
HERA IN THE HOMERIC HYMNS
}

\begin{abstract}
Summary: The paper deals with the features and functions of Hera in the Homeric Hymns. The corpus preserves a very short and trivial hymn to her (h.Hom. 12), two nearly identical references to her sleep during the birth of Hermes in the two Hymns devoted to him (h.Merc. 8 and h.Hom. 18. 8) and other minimal allusions (h.Ap. 95 and 99, h.Ven. 40). Especially interesting is the leading role played by Hera in two mythical episodes narrated in the Hymns: the binding and subsequent liberation of the goddess by Hephaistos in the the fragmentary Hymn to Dionysos (number 1 of the corpus) and the birth of Typhoeus, which was conceived as an act of revenge against Zeus for giving birth Athena (h.Ap. 305ss.). On the other hand, the myth of the Hymn to Apollo (305-338) is revisited attending to some striking Hittite parallels concerning the relationship between the oath by Heaven and Earth and the birth of a monstrous rival of the king of gods.
\end{abstract}

Key words: epithets, extraordinary births, Hittite myths, Homeric Hymns, legitimization, oath, rival, throne

\section{AIM}

It is something astonishing that, even though Hera is of great relevance to the Olympic pantheon, the collection of songs known as the Homeric Hymns dedicates to her only a hymn that is as brief as it is trivial (h.Hom. 12). The goddess is mentioned in others, some in passing or in a conventional manner, but in two of them her presence has a very interesting function. The aim of this paper is to elucidate the features and functions of Hera in all these passages. ${ }^{1}$

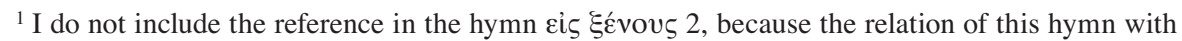
the others of the collection is very dubious. 
The hymn dedicated to Hera in the collection is extremely brief, as it contains only five verses. We lack evidence that would allow us to date the hymn and determine the place where it may have been performed. ${ }^{2}$ It is an atypical hymn due to its brevity and, above all, because of the absence of a final formula, hence it can be inferred either that only the beginning of a longer poem was included in the collection, or that the final formula was lost during the process of transmission of the text. The Hymn is as follows:

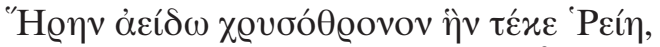

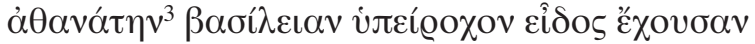

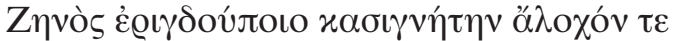

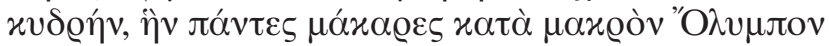

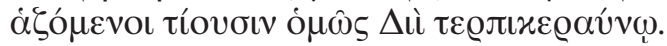

Of Hera I sing, the gold-throned, whom Rhea bore, the immortal queen, of supreme beauty, sister and wife of Zeus the loud-booming; glorious one, whom all of the blessed ones on long Olympus revere and honor no less than Zeus, whose sport is the thunderbolt. ${ }^{4}$

The principal aspect that the poet wants to highlight is the royal status of the goddess. This is reflected in the first epithet, $\chi \varrho v \sigma o ́ \theta \varrho o v o v$, whose translation as "gold-enthroned" seems to be more adequate than its relation to $\theta$ Qóv $\alpha$ "embroidered flowers". 5 This epithet associates the goddess with the throne, as well as with gold, a fundamental symbol of royalty and deities in archaic poetry. ${ }^{6}$ The author insists on this same aspect through the use of $\beta \alpha \sigma i ́ \lambda \varepsilon \iota \alpha$, a frequently used cultic title of Hera that reiterates her role as queen of the gods. ${ }^{7}$ Her relevance is multiplied, since the poet insists that her role as wife of the divine sovereign is combined with her position as sister, from the same

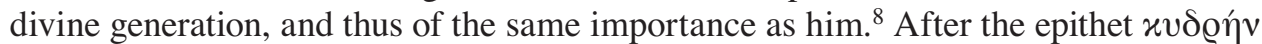
'glorious one' the brief hymn finishes with the notion that the other gods acknowledge her status as sovereign, the same status that is given to Zeus. It is therefore a hymn that conventionally focuses on what we could call the "institutional" aspect of Hera, as Samos.

${ }^{2}$ WEST $(2003,17)$ suggests that it may possibly have been composed for one of Hera's festivals on

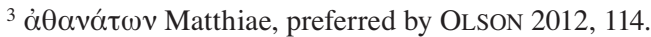

${ }^{4}$ Translation by M. West, as the others in this paper, but in this case with a correction in v. 2 because he accepts the conjecture $\dot{\alpha} \theta \alpha v \alpha ́ \tau \omega v$ by Matthiae, whereas I prefer the textus receptus.

${ }^{5}$ I prefer, with West, the traditional translation of the epithet. LAWLER $(1948,80-84)$ based on Il. 22.

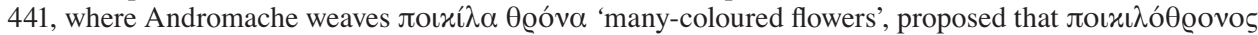
means 'with many-coloured embroidered flowers' and that all composita in - $\theta$ @óvo 'flowers embroidered on cloth', rather than with Ө@óvos 'throne'; for this, see JoUANNA's (1999) criticism.

${ }^{6}$ Cf. BERNABÉ 2014.

${ }^{7}$ e. gr. Phoronis fr. 4 BeRnABÉ, Pi. N. 1. 39.

${ }^{8}$ Both are children of Kronos and Rhea and were married, cf. Hes. Th. 453-457 and 921. 


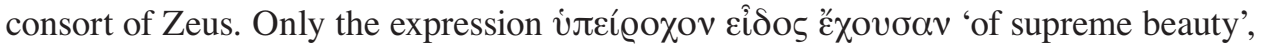
shows an external and formal concession to her feminine nature.

\section{SOME CONVENTIONAL MENTIONS}

3.1. In two hymns dedicated to Hermes there are nearly identical references to the fact that while Zeus unites with Maya to give birth to him, Hera is sleeping (h.Merc. 6-8

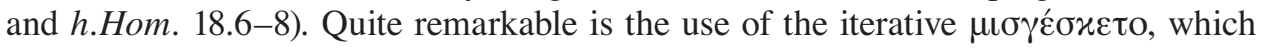
indicates reiterated infidelities by the god, emphasized by the presence of the ö $\phi \varrho \alpha$ particle in the following sentence that expresses duration. ${ }^{9}$

$$
\begin{aligned}
& \text { ع̌v } \theta \alpha \text { Kooví } \omega v
\end{aligned}
$$

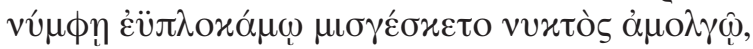

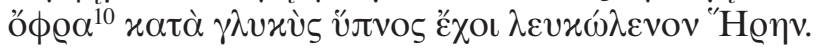

There the son of Kronos

used to unite with the nymph of lovely tresses in the depth of the night, so long as sweet sleep held white-armed Hera fast. ${ }^{11}$

It is an allusion to the clandestine union of Zeus and Maya. A scholion to Il. 24. 24 already pointed out that "Hermes's clandestine conception may point to his nature". ${ }^{2}$ On the other hand, the epithet $\lambda \varepsilon v \varkappa \omega \dot{\lambda} \lambda \varepsilon v o \varsigma$ is formular and it applies to goddesses and mortal women; it does not seem to have a special meaning. ${ }^{13}$ In any case, the role of Hera is passive; she is asleep while her husband is being unfaithful to her.

3.2. In the Hymn to Aphrodite the anecdote of the Hymn to Hermes is elevated to a general affirmation, since Zeus, extramarital affairs behind his wife's back are presented as a frequent happening due to the actions of Aphrodite herself (36-44).

\footnotetext{
${ }^{9}$ Cf. Vergados 2013, 226-227.

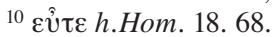

${ }^{11}$ Translation by West.

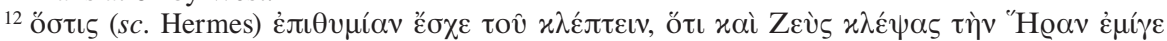
Maía, cf. VeRGADOS 2013, 228.

${ }^{13}$ As Vergados $(2013,277)$ points out, it is not correct in the case of NOVARO-LEFÈVRE's (2000, 46-52) remark, according to which "the divinities whose name or appelation contains the root $\lambda \varepsilon v x$ - have in common the protection of those travelling by sea and their association with death and initiatory rites".
} 


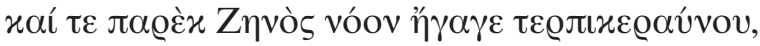

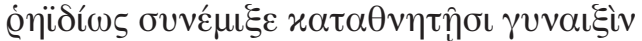

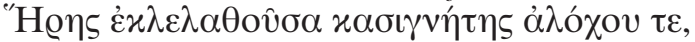

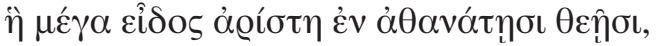

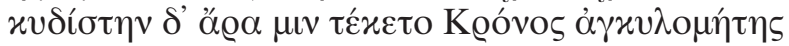

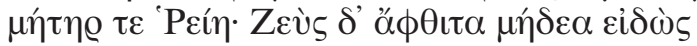

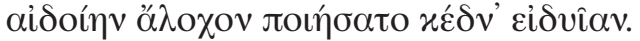

she even led astray the mind of Zeus whose sport is the thunderbolt, …

and easily coupled him with mortal women, putting out of his mind Hera his sister and consort, who is much the finest of aspect among the immortal goddesses, the most glorious daughter of crooked-schemer Kronos and the mother Rhea, and Zeus whose counseld do not fade made her his reverend consort, dutiful as she is.

However, the poet strongly highlights the contrast between the infidelities of Zeus and the beauty and institutional dignity of Hera, making the actions of Zeus to be inadequate and absurd. Such contrast is in accordance with the fact that Zeus decides to end his misdemeanor and control Aphrodite's absolute power. To this effect he makes the goddess to fall prey to the power that she exerts over everyone else, and makes her fall in love with a mortal. In this way, the "irregular" unions between gods and mortals are put to an end. This is inserted in one of the main characteristics of the hymns that have goddesses as the leading characters; the actions of Zeus reduce the initial power of a deity and places the world, particularly the divine world, in its right order. ${ }^{14}$

Some interesting thematic recurrences can be found between hymn 12, the h.Ven and the h.Merc., as can be seen in the following table:

\begin{tabular}{|c|c|c|}
\hline h.Hom. 12 & h.Ven. & h.Merc. \\
\hline 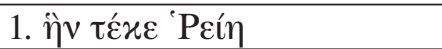 & 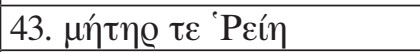 & \\
\hline 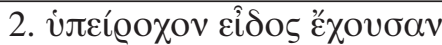 & 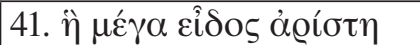 & \\
\hline 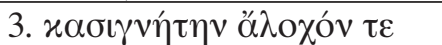 & 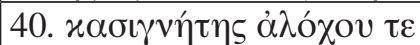 & \\
\hline & 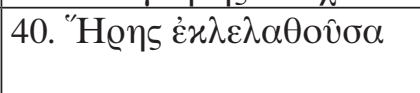 & 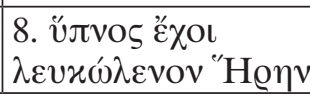 \\
\hline
\end{tabular}

3.3. In the Hymn to Apollo, Hera unleashes her vengeance against Zeus for his infidelities by preventing the intervention of Eileithyia, which causes long and painful labour pains to Leto, another of his husband's mistresses. First, the poet points out that, as it

${ }^{14}$ One of the central theses of CLAY 1989. 
is to be expected, Hera is not among the goddesses that accompany Leto during her lengthy labour in Delos (h.Ap. 92-95).

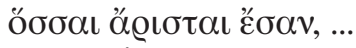

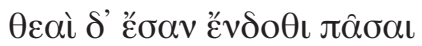

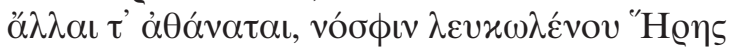

were in with her...

All the goddesses of high degree

and the other goddesses, apart from white-armed Hera.

He indicates afterward, however, that her role is not reduced to staying away, but that she is the one who caused the absence of Eileithyia, thus preventing Leto from giving birth (h.Ap. 97-101).

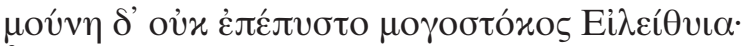

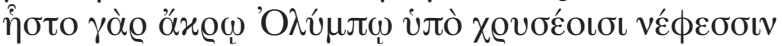

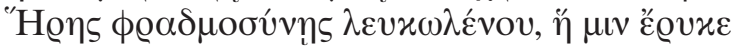

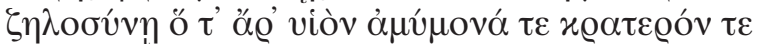

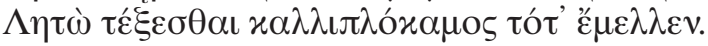

The only one who had not learned of it was the goddess of birth labor, Eileithyia, for he was seated atop Olympos under golden clouds

by the designs of the white-armed Hera, who was holding

her back out of jealousy, because lovely-haired Leto

was about to give birth to a fine strong son.

Like in the previous case, the epithet of Hera is uncharacterized: $\lambda \varepsilon v x \omega \dot{\lambda} \lambda \varepsilon v o s$. The same that appears again in the brief mention that closes Hera's actions, when the goddes decides to send Iris in search of Eileithyia, as always, behind her back (h.Ap. 105-106):

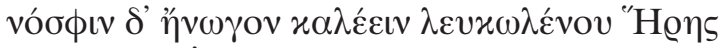

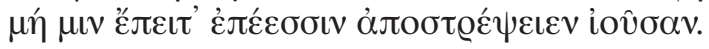

And they told her to summon her without reference to white-armed Hera, in case she should call her back.

\section{HERA IN THE HYMN TO DIONYSUS}

In the fragmented Hymn to Dionysus Hera plays a far more interesting role. The dating of Hymn I is controversial. Due to reasons that I will present elsewhere, ${ }^{15} \mathrm{I}$ find Merkel-

${ }^{15}$ BERNABÉ 2017, 22-23. 
bach's and West's arguments to consider it an archaic hymn (toward the end of the $7^{\text {th }}$ century BC) more appealing than Dihle's arguments in favour of considering it from the Hellenistic period. ${ }^{16}$ After a history of the text filled with difficulties, ${ }^{17}$ we owe to West $^{18}$ the disposition of the fragments of the hymn and a plausible reconstruction of its content.

In the first fragment, ${ }^{19}$ after a priamel where different versions of the birth of Dionysus are presented - all of which are false ( $\psi \varepsilon v \delta o ́ \mu \varepsilon v o \iota)-$, the poet establishes the one he considers to be true (h.Bacch. A 7-8):

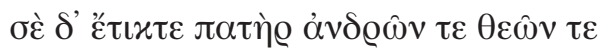

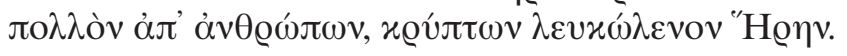

The father of gods and men gave you birth far from humankind, to conceal you from white-armed Hera.

The fact that in the preferred version of the poem it is Zeus who gives birth to Dionysus suggests that he follows the version where Zeus, having struck down Semele, carries on the pregnancy after sewing the fetus of Dionysus into his thigh. ${ }^{20}$

The poet thus perpetuates the cliché that any subject related to a son of Zeus must be hidden from Hera, and we find the common epithet $\lambda \varepsilon v x \omega \dot{\omega} \lambda \varepsilon v o{ }^{21}{ }^{21}$

Fragment $\mathrm{C}$ develops a mythical episode tightly related to Hera: the acceptance of Dionysus into Olympus. She had thrown her own son Hephaestus out of Olympus and he later gives her a throne to which he had attached a mechanism that prevents Hera from leaving the throne once she has sat down on it. Several gods try to make Hephaestus free her, until Dionysus inebriates him and takes him back to Olympus on a mule. Hera is thus liberated and, in gratitude, she accepts both Hephaestus and Dionysus into Olympus. ${ }^{22}$

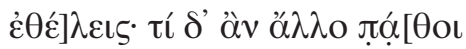

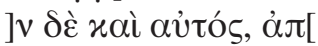

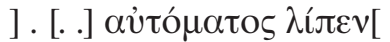

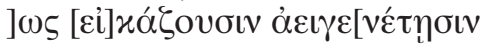

${ }^{16}$ Merkelbach 1973; West 2001, cf. 2003, 2011; Dihle 2002.

${ }^{17}$ Cf. Bernabé 2011b, West 2011.

18 WeSt 2001, cf. 2003, 2011. Contra, without convincing arguments CÀsSOLA 1975, 15.

19 The text is based in West's edition: the differences are signaled in the critical apparatus.

${ }^{20}$ Full versions: Apollod. 3. 4. 2, Ov. Met. 3. 273-298, Hyg. Fab. 167 and 179, but the myth is older; it is alluded by Pi. O. 2. 27-28 and E. Ba. 242-245, 286-295, 524-529. Concerning iconography, cf. an amphora by Diosphos Painter (ca. 500-490) and LIMC III 478, 666-668.

${ }^{21}$ Like in h.Ap. 95 and 99, h.Merc. 8 and h.Hom. 18. 8.

${ }^{22}$ Full versions of the myth: Paus. 1. 20. 3; ps.-Liban. Narr. 30. 1 (8. 38-39 Foerster), Aristid. Or. 41. 6, Hyg. Fab. 166; Serv. auct. Ecl. 4. 62. Nevertheless we find allusions to it in older authors: Alc. frs. 349a-e Voigt (ii. 152-153 Libermann); Pi. fr. 283; Epicharmus, PCG i. 51; Achaeus TrGF 20 F 16b-17; P1. R. 378d. 


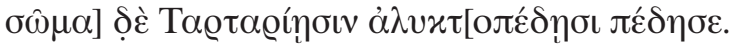

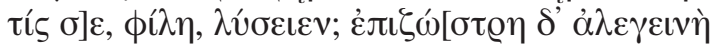

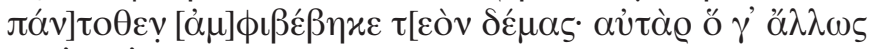

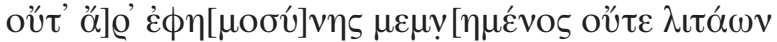

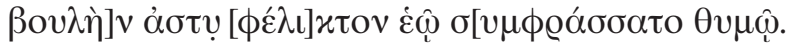

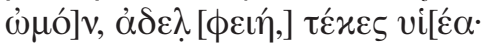

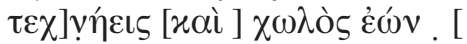

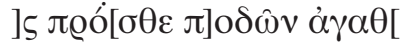

]

] $\mu \eta[$ [. . . . ]

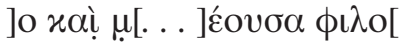

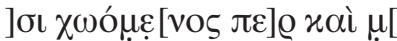

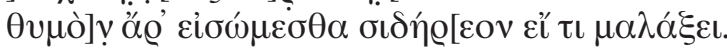

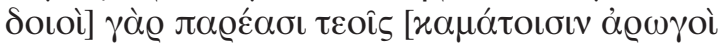

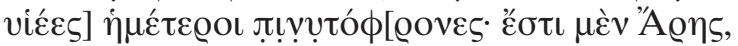

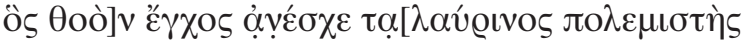

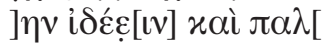

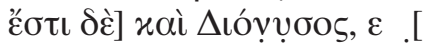

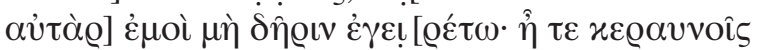

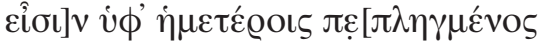

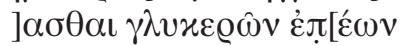

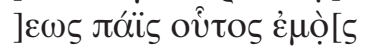

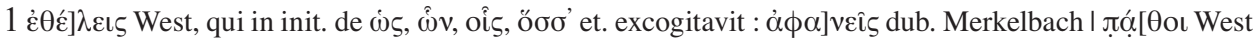

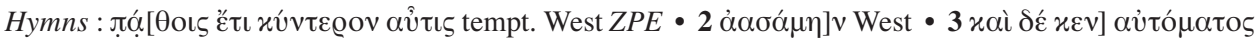

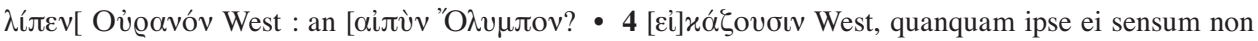

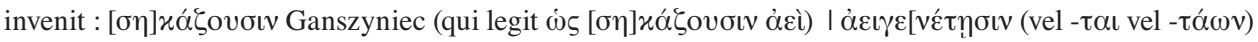

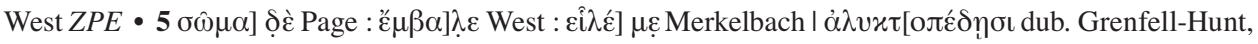

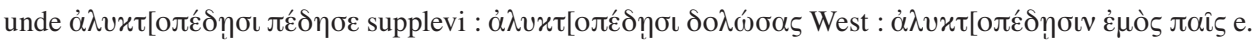

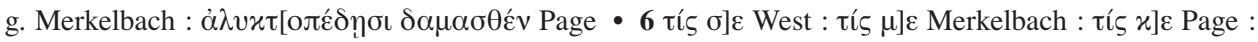

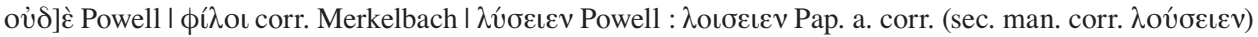

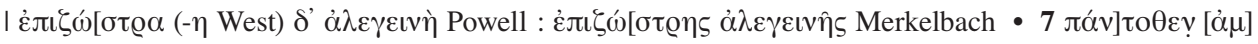

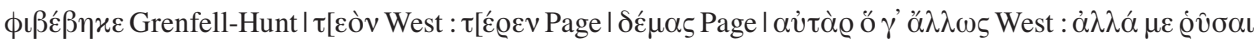

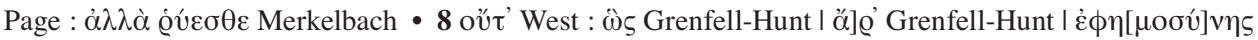

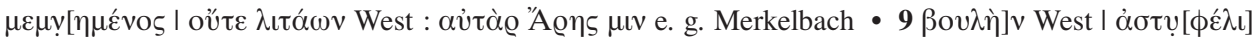

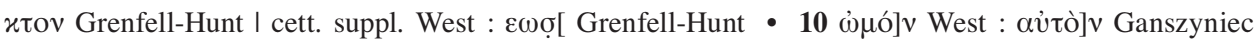

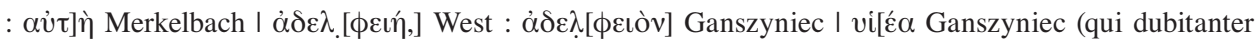

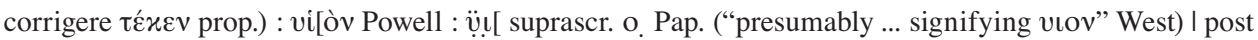

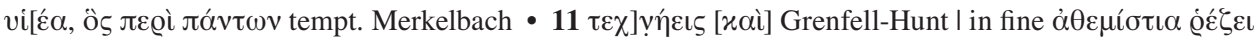

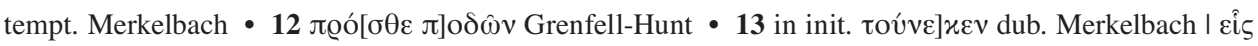

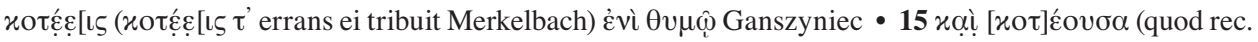

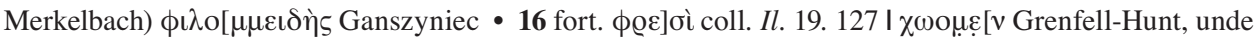

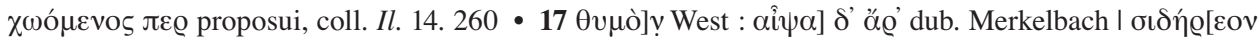

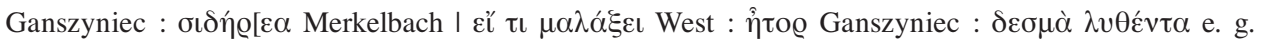




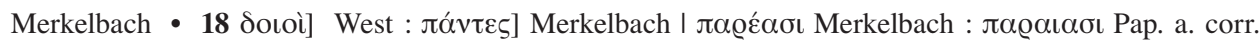

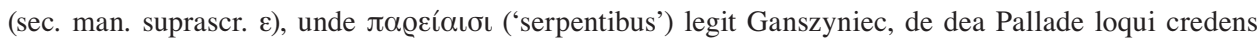

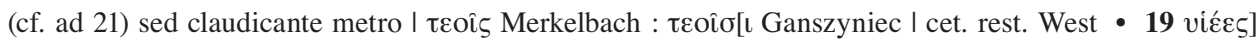

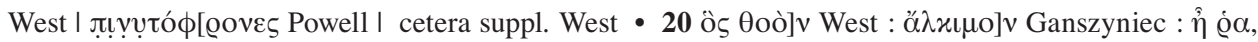

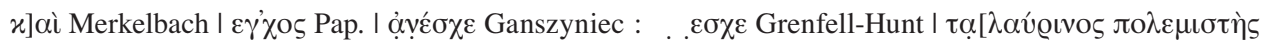

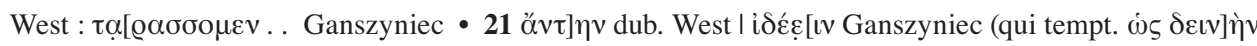

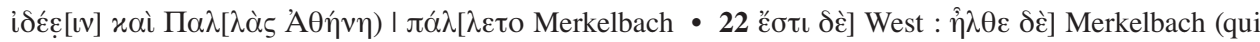

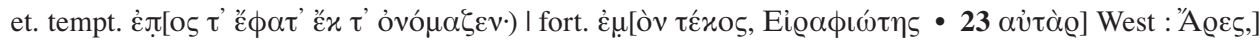

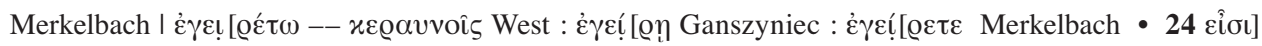

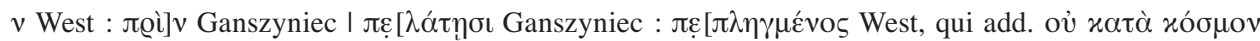

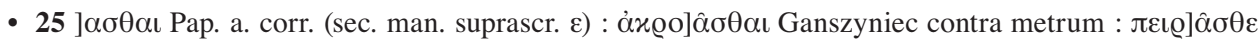

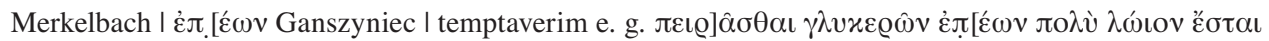

- $26 \dot{\varepsilon} \mu$ ọ̀[ऽ supplevi

" ... you wish. What else could happen to [you worse than this?

I was stupi]d myself, from [ ...

maybe he] would leave [high Olympos] of his own accord.

they are similar to ever[lasting

he bound your body] with hellisch fett[ers.

Who] could set y[ou] free, my dear? [A painful b]elt

encircles y[our body, while he,

heed[ing neither co]mmand [nor entreaty

has formed] an unshakeable r[esolve in his heart.

It is a cruel] son you have borne, sis[ter ...

craf $]$ ty even though a cripple $[\ldots$

... ] in front [of .... feet good [ ...

... ] probably [you are angry in your heart

... ] your [son ...

but although you are a]ngry [ ...

and he is also] angry ...

let us find out [if he will soften his hear]t of iron.

For there are [two] clever [sons] of mine at hand to [to help you

with] your [suffering. There is Ares,

who] has raised his [keen] spear, a th[ick-hide fighter

...] to look and bra[ndish ...;

and there is] also Dionysus [my son, the Eiraphiotes.

But let him] not stir up a quarrel with me, otherwise

he will be on his way belab]ored by my [thunderbolts ${ }^{23} \ldots$

... to make proof] of sweet [words would be much better

...] this son of mine [

${ }^{23}$ WEST $(2001,6)$ points out that Zeus is represented with a scepter and rays in the François Vase in which also the Hephaistos and Dionysus' return to Olympus is depicted. 
Taking into account the aforementioned versions of the myth, West proposed a plausible reconstruction of fragment $\mathrm{C} .{ }^{24}$ It would contain part of the conversation between Zeus and Hera once the goddess has been trapped by the arts of her son. Zeus seems to recognize that they have made a mistake in banishing Hephaestus and wonders who could free his wife. He then remembers the two sons who could help her: Ares, the great fighter and the personification of violence, and Dionysus, although Zeus fears he may provoke a conflict. It seems that Zeus, taking into consideration Hera's situation, considers it more appealing to convince Hephaestus through reasonable mediation rather than using force. In reality, there is one single option for Zeus, since he knows that Hephaestus will not be forced by violence. "The plan of Zeus" takes advantage of the situation and forces Hera, who is hostile against Dionysus (and all of Zeus's illegitimate progeny), to accept him into Olympus.

It is worth mentioning the association between Dionysus and Hephaestus that is presented in the hymn: both are marginal gods, Hephaestus because he was born only from Hera, ${ }^{25}$ was tossed out of Olympus and became deformed because of this action, and Dionysus because he was first born from a mortal, Semele, and later from the thigh of Zeus, hidden from Hera, which explains his initial distance from the immortals.

It would seem that the myth consecrates the legitimization of the two gods against Hera's wishes. The iconography of Dionysus leading a drunken Hephaestus on a mule or donkey to Olympus accompanied by a festive entourage is relatively popular in archaic representations. The oldest one known to us is that of the famous François Vase, dated to $570 \mathrm{BC} .^{26}$

On the other hand, Wilamowitz ${ }^{27}$ connected the origin of the myth with the Samian ritual of the Tonaia, a festival where an image ( $\beta \varrho \varepsilon ́ \tau \alpha \varsigma)$ of the goddess is bathed in the sea and later tied with branches of vitex agnus-castus tree. ${ }^{28}$ Nevertheless, the coincidence with the type of tree used to tie Hephaestus is not convincing enough to place the origin of the myth in Samos and relate it to a specific ritual that has its own etiological myth in the abduction of the statue by Tyrrhenian pirates. ${ }^{29}$ The festivities to which the myth acts as an aition are the trieteric festivities, which are celebrated in many places around Greece. Furthermore, the myth goes beyond a mere etiology and narrates the incorporation of Dionysus to the Olympic pantheon, symbolized by his reconciliation with Hera.

The role of Hera is therefore provided with additional context that infuses her character with greater depth, and moves her way from the simplistic role of step-mother who chases the sons of his husband. She hates Dionysus, but she accepts a reconcilia-

24 WEST 2001.

${ }^{25}$ Hes. Th. 927-929, fr. 343 M.-W. Homer ignores this detail (Zeus is mentioned as the god's father in Il. 1. 578-579, 14. 338-339; Od. 8. 312-313), cf. Apollodorus' (1. 3. 5) remark.

${ }^{26}$ Florence, Museo Archeologico, 4209. Cf. the complete analysis of archaic pieces by DíEZ PLATAS 2013, 348-357. According Paus. 1. 20. 2, the temple of Dionysus in Athens was also decorated with scenes of this myth.

${ }^{27}$ WilamOWITZ-MOELLENDORFF 1895, 234-235, followed by WEST (2001, 3-4; 2011, 33).

${ }^{28}$ Cf. Menodot. Sam. FGrHist 541 F 1.

${ }^{29}$ Cf. O’Brien 1993, 54-62; BAUMBACH 2004, 171-172; BuRKert 2011, 210-211. 
tion that allows the divine order to be instated with more stability, and both Hephaestus and Dionysus are accepted in Olympus. The resulting structure is the one suggested by $\mathrm{Clay}^{30}$ for long hymns in a double sense: it limits the excessive activity of a goddess (Hera) and it integrates "young” gods into Olympus (Dionysus and Hephaestus).

\section{HERA IN THE HYMN TO APOLLO}

Hera also plays a relevant role in a digression in the Hymn to Apollo. In his narration of the story of the female Dragon, the poet reminds the reader that she was the one who raised Typhaon (305-308). In a digression about the monster, the poet tells how Hera complains before the gods that Zeus had dishonored her because he had conceived Athena without her, and in turn had left her son, Hephaestus, maimed. We see again

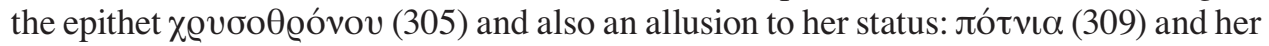

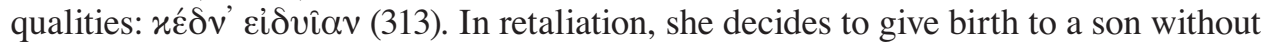
the participation of Zeus (309-330). She then goes far away from the gods, hits the ground and pronounces the following words:

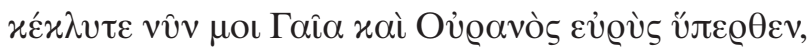

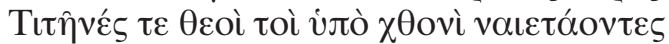

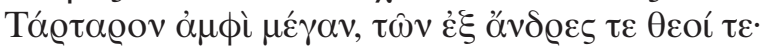

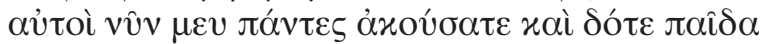

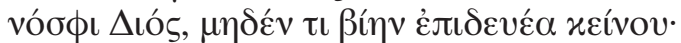

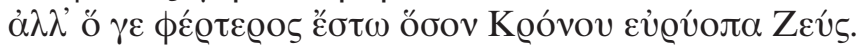

Hear me now, Earth and broad Heaven above,

and you Titan gods who dwell below the earth

around great Tartarus, and from whom gods and men descend.

all of you now in person, hear me and grant me a son

without Zeus' help, in no way falling short of him in strength,

but as much superior as wide-sounding Zeus is to Kronos.

She then hits the ground once more, and the earth with its tremor indicates that her vow will be fulfilled. Hera then retreats to her temple while the gestation takes place, and when Typhaon is born she entrusts her son to the female Dragon. The digression ends with the announcement that the monster would cause great pain to mankind.

On the one hand, the episode is parallel to Demeter's outrage in the hymn that carries her name because she was deprived of a daughter due to Zeus. She also tries to obtain a son through her own means (in this case, transforming Demophon into god), but she fails in her attempt and retreats to her temple. This causes great misfortunes to

${ }^{30}$ CLAY 1989, who points out that in the narratives of Apollo and Hermes, the births of the two gods require a rearrangement of the Olympian hierarchy, while Demeter and Aphrodite narrate a reordering of relations among gods and between gods and mortals. 
mankind not due to the offspring of a rival, but because of her refusal to make plants grow. Demeter later reaches an agreement with Zeus regarding Persephone's cyclical stays with her and with Hades. In the myth of the Hymn to Apollo there is no mention of an agreement because that is not a part of the argument of the poem but a digression, but it is obvious that a reconciliation is to be expected. In the same way there is no mention of the failure of the final attempt, which is mentioned in Hesiod's Theogony (820-880). Therefore it is clear that Hera does not intend to defy the power of Zeus to the point of trying to take away his powers through the monster. Instead, she only threatens her husband, invoking her position as her husband's equal.

However, if there is no reference to the reconciliation nor to the failure of the rival of Zeus, we have to wonder what is the motive behind the intrusion of this episode in the Hymn. West ${ }^{31}$ has argued that Cynaethus added the Hera-Typhaon section to the hymn to please Polycrates; as Hera was a relevant deity on Samos, this is something that cannot be proved or disproved and that requires the use of arguments that are external to the hymn to explain the episode. Felson, ${ }^{32}$ on the other hand, presents a more interesting interpretation stating that:

The important point about the Hera episode is how very theogonic the goddess's complaint, plan, and implementations are and how much they form a continuation of the theme of the myth of divine succession, with its goal of ensuring a stable seat forever,

and puts forward the contrasting roles of Leto and Apollo, who comply with the order of Zeus and the politics of Olympus by guaranteeing stability to the reign of the gods, with those of Hera and Typhaon, who constitute the counterpoint of the correct behavior, with a hostile and threatening attitude against Zeus.

From this perspective, the imprecation of Hera to the Earth and the Sky, the primordial couple in the Hesiodic Theogony, ${ }^{33}$ makes sense if we take into account that the goddess is trying to conceive a child without the mediation of a male, something that happened during the primitive phase of the Theogony, where some deities gave way to others in a non-sexual generation (for example, in the Hesiodic Theogony Gaia procreates Uranus equal to herself, to the hills and to the Sea without previous sexual union). ${ }^{34}$ The creature that she intends to give birth to will be, as she declares, a powerful rival to Zeus's control in the sky, and for that reason she resorts to using the Titans who arose against the sovereign powers of the gods and seriously threatened their power. In fact, the Typhonomachy in Hesiod is a sort of "second edition" to the Titanomachy, and the poet goes from one episode to another without interruption. ${ }^{35}$

${ }^{31}$ WEST 2003, 9-12.

${ }^{32}$ RiCHARDSON 2010, 275.

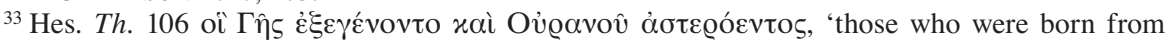
Earth and starry Sky'.

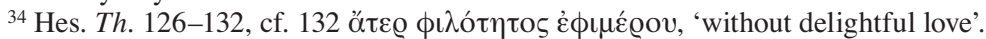

${ }^{35}$ Hes. Th. 820-822. 
Thus Hera includes Uranus and Gaia in her prayer because she intends to conceive a creature "in a primitive way", without the support of a male, and resorts to using the Titans because they are the most powerful rivals of Zeus and because she expects the creature to compete against Zeus.

\section{A HITTITE PARALLEL}

I have studied elsewhere ${ }^{36}$ some oriental parallels of Hera's oath that are found precisely in a cosmogonic context, in the fight for divine power. The most interesting one can be found in a poem of Hurrian-Hittite tradition called Song of Going Forth or Song of Kumarbi. ${ }^{37}$ The copy of the text available, which is very damaged, can be dated to the end of the $13^{\text {th }}$ century $\mathrm{BC}$, but the original text may date to the $16^{\text {th }}$ or $15^{\text {th }}$ centuries BC.

The text narrates the way in which the gods of successive generations usurp the power until Teshub manages to stop this chain of dethronements, and is victorious in his attempts to recover the kingdom from the defeated deities. In other poems from the cycle of Kumarbi, the defeated gods repeatedly try to create rivals agains Teshub, the god who is in power.

It is in the preface of the Song of Going Forth that we find the most relevant text for our purposes ${ }^{38}$

... who are Primeval Gods, let the $[.$. . ], weighty gods

listen: Nara, Napsara, Minki, (and) Ammunki! Let Ammezzadu listen!

Let $[\ldots$ and $\ldots$.$] , the father and mother of [\ldots]$ listen!

Let [ Anu and Antu?] the father and mother of [Ishara?], listen!

Ellil and NINLIL, who [below] and above (are) weighty, mighty deities,

let them listen!

The Hittite poet addresses determined deities to request their attention. The "primordial gods" (šiuneš karuilešs), often called Nara, Napsara, Ammunki, Tuhusi and Ammizadu, among others, are the ancient generation of gods who were defeated by younger gods and relegated to the subterranean world. ${ }^{39}$ Alalu is a deity of the earth, while Anu is the Mesopotamian god of the sky and Antu is his partner. Ishara is a Mesopotamian goddess that appears for the first time in the texts of Ebla and as the goddess of love in some enchantments. Her presence is often found as the guardian of

\footnotetext{
${ }^{36}$ BERNABÉ 2011a and 2014.

${ }^{37}$ Probably the titles "The Song of Kingship in Heaven" or "The Song of Kumarbi" are more familiar, cf. GARCía TRABAZO 2002, 155-175; LÓPEZ-RUIZ 2006; VAN DONGEN 2012; BERNABÉ 2015b, $129-152$.

${ }^{38}$ I follow the text by García Trabazo 2002, 160-162. Translation by HofFner 1998, with little changes.

${ }^{39}$ Cf. Laroche 1974.
} 
oaths. The god Enlil, a deity of the atmosphere, and his partner the goddess Ninlil are of Sumerian origin, and they are the parents of the moon god Sin.

The poet does not indicate the source of his knowledge, but he seems to use the gods who know about the topic as witnesses and guarantors of truth, since they are the most ancient ones and because they were the protagonists of the events in the narrative.

In both texts we can find a series of similar elements:

a) Someone addresses a series of gods from whom they demand attention using the imperative. In the Hittite poem the author uses the gods as witnesses, while Hera tries to exert them into helping her to conceive a child. The cause, that leads Hera and the poet to this contact with the gods, either because their help is required or because they are needed as witnesses, must be their primeval character, which makes them knowledgeable of all the happenings in the world, and their traditional hostility toward the "new" deity that is occupying power.

b) In both cases the verb "to hear" is reiterated. As it is known, the reiteration is a magical procedure with a performative value.

c) They both coincide in mentioning primeval gods locked in the underworld and/or a god of the Sky.

d) The invoked deities still have a generative power ${ }^{40}$ even though they are no longer in power: the Hymn to Apollo specifies this considering, that "gods and men" come from the Titans; in the Hittite text the author alludes to this power by insisting on naming the mentioned gods as fathers (and) mothers.

e) In the Hymn, Hera's invocation is made because the goddess, moved by spitefulness, wishes to create a rival to Zeus that will be more powerful than him; in the Song of Going Forth the invocation is to call the gods to make them witnesses of the account, but the story is precisely about how Kumarbi creates a rival against Tesub.

f) The rival is also related to extraordinary births: Hera becomes pregnant without a male, Ullikummi is the product of the union between Kumarbi and a rock. The rival is thus created using methods from the era that preceded order.

Nonetheless there are important differences in the scenes:

i) In regards to the function of the invocation, in the Hittite text the poet puts the primeval gods as witnesses of his poem, apparently because he wants to use them as guarantors of the veracity of the tale. ${ }^{41}$ In the Hymn to Apollo Hera's invocation, also accompanied by the actio magica, has a performative effect-not a literary one-inside the text, since the goddess manages to create Typhaon, but the text of the Hymn does not have a ritual character.

ii) The speakers of the formula and their motivations are different. In the Hittite text, the speaker is a poet who wants to produce an effect that lies between a religious and a literary effect: the veracity and the acceptance of his poem. In the Hymn it is

\footnotetext{
${ }^{40}$ In Derveni Cosmogony, for example, Zeus swallows Uranus' phalus and becomes pregnant of all the creation. Cf. BERNABÉ 2008, 268-270.

${ }^{41}$ It is noteworthy that in the Hymn to Apollo 1 there is not an invocation of the Muse, but the poet

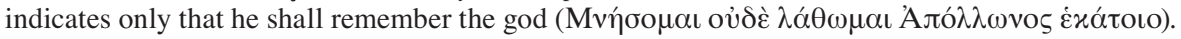


a goddess, Hera, who wants to produce an effect to get revenge against Zeus for the humiliation that she has suffered.

iii) The motive behind the creation of a rival is found in the Hymn tightly associated with the formula, since this, through the concomitant actio magica, gives way directly to the creation of Typhaon. In the Hittite poem, this connection is not as intertwined; the formula refers to the narrative, while the creation of the rival happens later within the narrative.

iv) The person who creates the rival and their motives is also different. Kumarbi is the one who does it in the Hittite poems, and his motive is to recover the power of the Sky dethroning the current king of the gods. In this context resorting to primeval deities makes more sense than in the case of Hera, who does not intend to alter the divine power nor provoke a return from $x$ ó $\sigma \mu \varsigma$ to the original chaotic situation (a Greek poet would not imagine such thing, nor would he present Hera as the leader of said action). Instead, Hera wishes to unleash her resentment against Zeus and threaten him. Hera does not play the same role as Kumarbi, who in the Hittite world is a constant threat, since the rivals that he creates constantly dethrone Tesub. The Greek Titans, once defeated by Zeus, are thrown into the underworld to never come back. Typhaon also fails to dethrone Zeus, causing only a minor inconvenience. He ends up tossed on a beach or under Mount Etna depending on the version of the story. The power of Zeus is indisputable and is established for eternity, unlike the unstable power of the divine kings of Oriental cultures (at this point the Hittite myths are similar to those of the Babylonians and the people from Ugarit), where we can see how the reigning gods are dethroned, killed, dismembered, or sent to hell, although some return once again. ${ }^{42}$

\section{CONCLUSION}

Hera appears in the Hymns occupying a high position in the pantheon's hierarchy and in her institutional role (both are marked by the epithet $\chi \varrho v \sigma o ́ \theta \varrho o v o \varsigma$ ) as sister and wife of Zeus. Additionally, she also appears in a rather irksome role as a betrayed wife or offended by the illegitimate children of his husband, whose conception or birth she tries to prevent. The beauty of the goddess is a recurrent motif in the texts (most of the times using the epithet $\lambda \varepsilon v x \omega \dot{\nu} \lambda \varepsilon v o \varsigma)$. The episodes from the Hymn to Demeter and the Hymn to Apollo are fundamental for a better understanding of Hera's portrait in the Hymns, a literary gender in which (according to the seminal studies by Jenny Clay) the roles of the gods ("ॄ@ $\gamma \alpha$ and $\tau \iota \mu \alpha$ í) are definitively defined. The trickery of Hephaestus put into play in the Hymn to Demeter forces Hera to accept a reconciliation with him, and to accept both Hephaestus and Dionysus as gods of the Olympus in their own right. In the myth of the Hymn to Apollo Hera is angered because Zeus has given birth to Athena without her help, and in retaliation she tries to conceive a rival of Zeus on her own: Typhoeus. When the Hymn is compared to the Hittite Song of Going Forth

${ }^{42}$ Cf. Bernabé 2008, 291-305. 
or Song of Kumarbi, striking parallels concerning the relationship between the oath by Heaven and Earth and the birth of a monstrous rival of the king of gods are found.

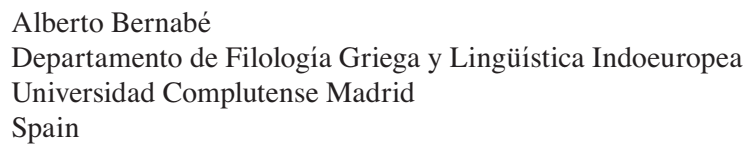

\section{BIBLIOGRAPHY}

Baumbach, J. D. 2004: The Significance of Votive Offerings in Selected Hera Sanctuaries in the Peloponnese, Ionia and Western Greece. Oxford

BERnABÉ, A. 2008: Dioses, héroes y orígenes del mundo. Madrid

BERNABÉ, A. 2011a: Invocar a los dioses primigenios: el juramento de Hera (h.Ap. 330-339) y el proemio del Canto de Kumarbi hitita, entre la magia y la literatura. In Studia Mystica, Magica et Mathematica ab Amicis, Sodalis et Discipulis Iosepho Ludovico Calvo oblata [MHNH 11], pp. 259-272.

BERnABÉ, A. 2011b: El Himno homérico a Dioniso: el dios nacido del muslo de Zeus. In Pàmias, J. (ed.): Parua Mythographica. Oberhaid, pp. 33-44.

BERNABÉ, A. 2014: Riferimenti all'oro nei poemi di Pindaro: simboli e connotazioni. In Tortorelli Ghidini, M. (a cura di): Aurum. Funzioni e simbologie dell'oro nelle culture del Mediterraneo antico. Roma, pp. 303-313.

BERnABÉ, A. 2015a: To Swear to Heaven and Earth, from Mesopotamia to Greece. In Rollinger, R. - van Dongen, E. (eds): Mesopotamia in the Ancient World. Impact, Continuities, Parallels. Proceedings of the Seventh Symposium of the Melammu Project Held in Obergurgl, Austria, November 4-8, 2013. Münster, pp. $125-134$.

BERNABÉ, A. 2015b: Mitos hititas. Entre oriente y occidente. Madrid

BERNABÉ, A. 2017: Himnos homéricos, edición, traducción y notas. Madrid

BURKERT, W. 2011: Griechische Religion der archaischen und klassischen Epoche. 2. Auflage. Stuttgart

CÀssola, F. 1975: Inni Omerici. Milano

Clay, J. S. 1989: The Politics of Olympus, Princeton [2nd ed. 2006]

DíEz Platas, F. 2013: Dioniso en la figuración arcaica. In Bernabé, A. - Jiménez San Cristóbal, A. I. - Santamaría, M. A. (coord.): Dioniso. Los orígenes (Textos e imágenes de Dioniso y lo dionisíaco en la Grecia Antigua). Madrid, pp. 275-399.

Dihle, A. 2002: Zu den Fragmenten eines Dionysos-Hymnus. RhM 145, pp. 427-430.

DONGEN, E. VAN 2012: The Hittite Song of Going Forth (CTH 344): A Reconsideration of the Narrative. Die Welt des Orients 42, pp. 23-84.

FAUlKneR, A. (ed.) 2011: The Homeric Hymns. Interpretative Essays. Oxford

FELson, N. 2011: Children of Zeus in the Homeric Hymns. Generational Succession. In A. Faulkner (ed.): The Homeric Hymns. Interpretative Essays. Oxford, pp. 254-279. 
García Trabazo, J. V. 2002: Textos religiosos hititas. Madrid

HOFFner, H. A. 1998: Hittite Myths. 2nd ed. Atlanta

JOUANNA, J. 1999: Le trône, les fleurs, le char et la puissance d'Aphrodite. (Sappho I, v. 1, 11, 19 et 22). Remarques sur le texte, sur les composés en - $\theta$ @ovo 5 et sur les homérismes de Sappho. Revue des études grecques 112, pp. 99-126.

LAROCHE, E. 1974: Les dénominations des dieux 'antiques'. In Bittel, K. et al. (eds): Anatolian Studies presented to H. G. Güterbock on the occasion of his 65th birthday. Istanbul, pp. 175-185.

LAWler, L. B. 1948: On Certain Homeric Epithets. Philological Quarterly 27, pp. 80-84.

LÓPEZ-RuIZ, C. 2006: Some Oriental Elements in Hesiod and the Orphic Cosmogonies. Journal of Ancient Near Eastern Religions 6, pp. 71-104.

MERKELBACH, R. 1973: Ein Fragment des Homerischen Dionysos-Hymnus. Zeitschrift für Papyrologie und Epigraphik 12, pp. 212-215 ( = Philologica. Ausgewählte Kleine Schriften, Stuttgart-Leipzig 1997, pp. 35-37).

Novaro-Lefèvre, D. 2000: Le culte à Hera de Perachora (VIII-VIe s.) : essai de bilan. Revue des études grecques 113, pp. 42-69.

O'BRIEN, J. 1993: The Transformation of Hera: a Study of Ritual, Hero, and the Goddess in the Iliad. Lanham

Olson, S. D. 2012: The 'Homeric Hymn to Aphrodite' and Related Texts. BerlinBoston

Richardson, N. 2010: Three Homeric Hymns: To Apollo, Hermes, and Aphrodite. Hymns 3, 4, and 5. Cambridge

Vergados, A. 2013: The 'Homeric Hymn to Hermes'. Introduction, Text and Commentary. Berlin-Boston

WEST, M. L. 2001: The Fragmentary Homeric Hymn to Dionysus. Zeitschrift für Papyrologie und Epigraphik 134, pp. 1-11.

WeSt, M. L. 2003: Homeric Hymns. Homerica Apocrypha. Lives of Homer. Cambridge, MA-London

West, M. L. 2011: The First Homeric Hymn to Dionysos. In Faulkner, A. (ed.): The Homeric Hymns. Interpretative Essays. Oxford, pp. 29-43.

WilamowitZ-MOELLENDORFF, U. VON 1895: Hephaistos. Nachrichten von der Königlichen Gesellschaft der Wissenschaften zu Göttingen (phil.-hist. Klasse), pp. 217-245. 